\title{
PENERAPAN PEMBELAJARAN MODEL ELICITING ACTIVITIES TERHADAP KEMAMPUAN BERFIKIR KRITIS MAHASISWA
}

\author{
Mira Marlina ${ }^{1}$, Sri Sukmawati ${ }^{2}$, Anton Nasrullah ${ }^{3}$ \\ 1,2,3 Universitas Bina Bangsa \\ 1mira.marlina@binabangsa.ac.id, ${ }^{2}$ sri.sukmawati@binabangsa.ac.id, ${ }^{3}$ anton.nasrullah@bina bangsa.ac.id
}

\begin{abstract}
ABSTRAK
Tujuan Penelitian adalah untuk mengetahui apakah pencapaian kemampuan berfikir kritis mahasiswa pada pembelajaran matematika ekonomi kelas eksperimen (MEAs) lebih baik daripada kelas kontrol (konvensional). Metode yang digunakan dalam penelitian adalah metode kuasi eksperimen dengan desain penelitian pretest-posttest control group design. Tempat penelitian dilaksanakan disalah satu universitas di Banten. Sampel diambil dua kelas secara purposive. Sampel penelitian yang dipilih terdiri dari dua kelas yaitu 37 mahasiswa kelas eksperimen dan 38 mahasiswa kelas control. Instrumen penelitian yang digunakan adalah tes kemampuan berfikir kritis. Hasil penelitian menunjukan bahwa pencapaian kemampuan berfikir kritis mahasiswa kelas eksperimen (MEAs) lebih baik daripada kelas kontrol (konvensional) pada pembelajaran matematika ekonomi.
\end{abstract}

Kata Kunci : model eliciting activities, kemampuan berfikir kritis, konvensional.

\begin{abstract}
The purpose of this study was to determine whether the achievement of students' critical thinking skills in learning mathematics in the experimental class (MEAs) was better than the control class (conventional). The method used in this research is a quasi-experimental method with a pretest-posttest control group design research design. The place of research was conducted at a university in Banten. Samples were taken two classes purposively. The chosen research sample consisted of two classes, 37 experimental class students and 38 control class students. The research instrument used was a test of critical thinking skills. The results showed that the achievement of critical thinking skills of experimental class students (MEAs) was better than the control class (conventional) in learning economics mathematics.
\end{abstract}

Keywords: model eliciting activities, critical thinking skills, conventional.

\section{PENDAHULUAN}

Keberlangsungan dalam proses belajar mengajar matematika pada penyampaian dan menyajikan masih berpusat pada dosen (Farida, 2015; Rahmawati, 2016). Pembelajaran langsung biasanya disertai dengan metode pembelajaran seperti diskusi, tanya jawab pemberian tugas dan sebagainya namun, mahasiswa menerima materi yang sudah jadi. Mahasiswa tidak diajak untuk berfikir dan menggunakan pengalaman belajarnya. Oleh karena itu salah satu metode pembelajaran yang dianggap dapat mengembangkan kemampuan berpikir kritis mahasiswa adalah pendekatan Model Eliciting Activities (MEAs). Pendekatan Model Eliciting Activities menggali kompetensi peserta didik dalam mengurai elemen-elemen, memahami hubungan konsep antar elemen, serta 
mengidentifikasi aturan yang berlaku untuk hubungan dan operasi (Afrilianto, 2015). Hal ini, peserta didik diarahkan dalam membangun kompetensi mereka dalam proses berfikir sehingga dapat memberikan solusi terhadap permasalahan yang disajikan.

Secara etimologi, ada tiga kata yang dapat dikaji, yaitu model, eliciting, dan activity. Jika diterjemahkan dalam bahasa Indonesia model dapat diartikan sebagai rumus atau langkah-langkah yang digunakan untuk menyelesaikan masalah matematika. Eliciting artinya membangun atau membentuk. Activity artinya aktivitas. Dari tiga kata tersebut jelas bahwa model eliciting activities (MEAs) adalah kegiatan membangun atau membentuk rumus atau langkah-langkah untuk menyelesaikan masalah matematika (Yuliardi., \& Habibi., 2016). Kegiatan pembelajaran MEAs membentuk peserta didik untuk mengembangkan model matematika yang merupakan sistem konseptual sehingga peserta didik memperoleh berbagai macam pengalaman matematika (Chamberlin., \& Moon, 2008).

Pendekatan utama dalam pembelajaran yaitu; a) pendekatan yang berpusat pada dosen/guru (teacher-centered approaches) dan; b) pendekatan yang berpusat pada peserta didik (student-centered approaches) (Syah., 2006). Pendekatan model eliciting activities (MEAs) adalah salah satu pendekatan yang berpusat pada peserta didik yang memungkinkan untuk dapat lebih aktif dalam melakukan kegiatan belajar di dalam kelas. model eliciting activities (MEAs) terbentuk untuk memenuhi kebutuhan pengguna kurikulum. MEAs dikembangkan oleh guru matematika, professor, dam mahasiswa pasca sarjana di Amerika dan Australia, untuk digunakan oleh guru matematika (Chamberlin., \& Moon, 2008). Ada dua alasan terbentuknya MEAs, yang pertama MEAs akan mendorong peserta didik untuk membuat suatu model matematika untuk memecahkan masalah yang rumit, seperti yang biasa seorang ahli matematika lakukan di kehidupan nyata; kedua, MEAs dirancang untuk memungkinkan para peneliti menyelidiki kemampuan berpikir kritis matematika peserta didik (Istianah, 2013; Muzaki, 2014; Hidayat, 2014).

Kemampuan berpikir kritis matematis adalah kemampuan matematika tingkat tinggi diukur dengan menggunakan; a) kemampuan mengidentifikasi dan menjastifikasi konsep, yaitu kemampuan memberikan alasan terhadap penguasan konsep; b) kemampuan menggeneralisasi, yaitu kemampuan melengkapi data atau informasi yang mendukung; c) kemampuan menganalisis algoritma, yaitu kemampuan mengevaluasi atau memeriksa suatu algoritma (Zetriuslita., Ariawan., \& Nufus, 2016). Berpikir kritis adalah mengelompokkan, mengorganisasikan, mengingat dan menganalisis informasi. 
Kemampuan berpikir kritis dapat membuat dan melatih seseorang untuk melakukan (doing math) dalam pembelajaran matematika.

Kemampuan berpikir kritis dan berpikir kreatif dalam taksonomi Bloom terbaru, merupakan indikator kemampuan berpikir tingkat tinggi. Dimana berpikir kritis adalah suatu proses intelektual yang aktif dan penuh dengan keterampilan dalam membuat pengertian atau konsep, mengaplikasikan, menganalisis, membuat sintesis, dan mengevaluasi (Krathwohl., \& Anderson, 2009). Kegiatan berpikir di dalam kelas tidak terlepas jauh dari aktivitas berpikir kreatif dan berpikir kritis. Berpikir kritis adalah melatih atau memasukan penilaian atau evaluasi yang cermat, seperti menilai kelayakan suatu gagasan atau produk. Dalam berpikir kritis juga bertujuan untuk memberi pertimbangan atau keputusan mengenai sesuatu (Noordyana, 2016).

Berpikir kritis adalah sikap penyelidikan yang melibatkan kemampuan untuk mengenali keberadaan dan penerimaan kebutuhan umum untuk bukti dalam apa yang ditegaskan untuk menjadi kenyataan, dari kesimpulan yang valid, abstraksi di mana bobot akurasi berbagai jenis bukti ditentukan secara logis, dan keterampilan dalam menggunakan dan menerapkan di atas sikap dan pengetahuan berpikir kritis (Noordyana, 2016). Adapun alasan untuk membiasakan pembelajaran yang dapat menumbuh kembangkan berpikir kritis adalah: a) berpikir kritis dapat memperbaiki efektivitas kemampuan berpikir manusia; b) berpikir kritis dapat cepat mengembangkan berpikir urutan-tertinggi (higherorder thinking) dan kemampuan literacy.

Terkait dengan paradigma bahwa efektifitas proses pembelajaran berkaitan erat dengan prinsip pembelajaran student-centered learning dimana dalam kegiatan belajar peserta didik harus menjadi individu yang aktif dalam membentuk pengetahuan, dapat menentukan sendiri proses belajarnya, memilih pengalaman belajar serta pengetahuan utama yang ingin dicapainya. Selain itu, terdapat pandangan bahwa pembelajaran inovatif mendasarkan diri pada paradigma konstruktivistik. Kosntruktivis merupakan pembelajaran matematika yang efektif yaitu ketika peserta didik berkembang dari pengalaman kongkret menuju gambar-gambar sehingga mampu menggunakan representasi simbolis dengan memanfaatkan pengetahuan yang telah diterima, dan peserta didik dapat menggunakan pengetahuan yang baru secara aktif untuk mengkonstruksi makna (Smith, 2010). Hal tersebut mengindikasikan bahwa pada proses pembelajaran yang efektif dan inovatif, peserta didik tidak sekadar menjadi penerima informasi yang pasif melainkan harus berpikir kritis dan kreatif tentang topik yang dipelajari. 
Indikator dan sub-indikator menurut Krathwohl \& Anderson (2009) mengenai berpikir kritis adalah; a) interpretasi (interpretation): pengkategorian, membuat makna kalimat, pengklasifikasian makna; b) analisis (analysis): menguji dan memeriksa ide-ide, mengidentifikasi argument, menganalisis argumen; c) evaluasi (evaluation): mengevaluasi dan memepertimbangkan klain/pernyataan, mengevaluasi dan mempertimbangkan argumen; d) penarikan kesimpulan (inference): menyangsikan fakta atau data, membuat berbagai alternative konjektur;menjelaskan kesimpulan; f) penjelasan (explanation): menuliskan hasil, mempertimbangkan prosedur, menghadirkan argument; g) kemandirian (self-regulation): melakukan pengujian secara mandiri: melakukan koreksi secara mandiri.

Berdasarkan penelitian-penelitian terdahulu, dalam proses belajar mengajar dengan MEAs terdapat perbedaan yang signifikan antara peningkatan kemampuan representasi matematis peserta didik kelompok atas, kelompok tengah dan kelompok bawah dan terdapat interaksi antara faktor pembelajaran dengan faktor kategori kemampuan peserta didik dalam lingkup kemampuan representasi matematis (Facione, 2011) dan dapat meningkatkan representasi hasil belajar peserta didik (Hamidah, 2014). Tahapan dalam pembelajaran pendekatan MEAs dapat mengembangkan kemampuan berpikir mahasiswa, karena setiap tahap pembelajaran membutuhkan kemampuan dalam mengidentifikasi masalah, memberikan alasan, memberikan banyak jawaban yang berbeda-beda. Jadi, melalui MEAs merupakan upaya pendekatan pembelajaran yang berusaha membuat mahasiswa terlibat secara aktif dalam kegiatan pembelajaran matematika ekonomi di dalam kelas. Keterlibatan mahasiswa dalam proses belajar mengajar secara aktif diharapkan mahasiswa dapat berpikir secara kritis.

Berdasarkan masalah diatas maka rumusan masalah adalah pencapaian kemampuan berfikir kritis mahasiswa pada pembelajaran matematika ekonomi kelas eksperimen (MEAs) lebih baik daripada kelas kontrol (konvensional) ?. Adapun manfaat penelitian adalah memberikan alternatif pembelajaran sebagai salah satu solusi meningkatkan kemampuan kompetitif mahasiswa yaitu kemampuan berfikir kritis untuk memecahkan masalah dalam menghadapi kebutuhan industry yang dinamis (revolusi industri 4.0).

\section{METODE PENELITIAN}

\section{Rancangan Penelitian}

. Studi quasi-experiment dirancang untuk membandingkan berfikir kritis mahasiswa dalam pembelajaran matematika ekonomi. Pada kelas kontrol, mahasiswa dengan metode 
biasa (konvensional) sedangkan kelas eksperimen diberikan pembelajaran MEAs. Kedua kelas dimulai dengan studi dalam pengaturan tatap muka selama 6 minggu diterapkan kepada mereka. Mahasiswa pada kelas eksperimen diberikan dengan pembelajaran MEAs, sedangkan mahasiswa pada kelas kontrol yang terlibat dengan tatap muka belajar hanya didalam kelas dengan metode biasa.

\section{Subjek Penelitian}

Peneilitian dilakukan di perguruan tinggi negeri Universitas Islam Negeri Sultan Maulana Hasanuddin Banten Jurusan Ekonomi Syariah yang memiliki 240 mahasiswa di semester 2, tahun akademik 2018/2019. Sebuah pilihan pendekatan kuanitatif dengan metode quasi-experiment desain penelitian non-equivalent control group (McMillan., \& Schumacher, 1997). Proses penelitian, tidak membuat kelas yang baru melainkan kelas yang sudah ada kemudian dipilih untuk menentukan kelas eksperimen dan kelas kontrol yang memiliki karakteristik hampir sama. Sampel berasal dari dua kelas. Satu kelas digunakan untuk kelas kontrol sebanyak 38 Mahasiswa dan kelas eksperimen sebanyak 37 Mahasiswa. Pembelajaran matematika ekonomi berlangsung selama 6 minggu dalam satu semester dengan setiap pertemuan di kelas sekali seminggu selama 150 menit.

\section{Analisis Data}

Data yang diperoleh dari tes kemampuan berfikir kritis dalam pembelajaran matematika ekonomi dianalisis secara kualitatif. Pre-test diberikan sebelum perlakuan dan untuk memastikan bahwa kelas ekperimen dan kelas control memiliki kesetaraan kemampuan (homogen) dengan uji independent t-test. Pengolahan data diawali dengan menguji persyaratan statistik yang diperlukan sebagai dasar dalam rangka pengujian hipotesis, yaitu uji normalitas dan uji homogenitas varians untuk setiap kelas data yang diuji. Setelah data memenuhi syarat normal dan homogen, selanjutnya dilakukan uji perbedaan rata-rata menggunakan uji-t yaitu independent sample-test. Apabila data normal dan tidak homogen maka pengujian perbedaan rata-rata menggunakan uji-t'. Namun, apabila salah satu atau kedua kelas berdistribusi tidak normal, maka pengujian data menggunakan uji Mann-Whitney U digunakan untuk mengetahui apakah kelas eksperimen memperoleh kemampuan berfikir kritis lebih baik daripada kelas kontrol.

\section{HASIL DAN PEMBAHASAN}

Berdasarkan hasil analisis deskriptif (Tabel 1) menunjukan bahwa terdapat peningkatan skor rata-rata kemampuan Berfikir Kritis matematis mahasiswa sebelum dan 
sesudah perlakuan. Pada kelas MEAs terdapat peningkatan sebesar 28.35, sedangkan pada kelas konvensional sebesar 20.34.

Tabel 1. Deskripsi Data Kemampuan Berfikir Kritis

\begin{tabular}{lcccc}
\hline \multirow{2}{*}{ Deskripsi } & \multicolumn{2}{c}{ MEAs } & \multicolumn{2}{c}{ Konvensional } \\
\cline { 2 - 5 } & Pre-test & Post-test & Pre-test & Post-test \\
\hline Reratra & 43.38 & 71.73 & 44.53 & 64.87 \\
Max & 69 & 91 & 58 & 94 \\
Min & 31 & 55 & 36 & 50 \\
SD & 10.40 & 11.04 & 5.78 & 11.46 \\
\hline
\end{tabular}

Analisis skor pre-test menggunakan uji perbedaan rataan. uji perbedaan rataan bertujuan untuk memperlihatkan ada tidaknya perbedaan secara signifikan antara kemampuan berfikir kritis mahasiswa pada kelas MEAs dan konvensional. Sebelumnya, terlebih dahulu dilakukan uji prasyarat normalitas untuk mengetahui berdistribusi normal atau tidak. Uji normalitas skor pre-test dihitung dengan uji statistik Kolmogorov-Smirnov pada taraf signifikansi $\propto=0,05$.

Tabel 2. Uji Normalitas Skor Pre-Test Kemampuan Berfikir Kritis

\begin{tabular}{|c|c|c|c|c|c|}
\hline \multirow{2}{*}{ Kelas } & \multicolumn{3}{|c|}{ Kolmogorov-Smirnov $^{\text {a }}$} & \multirow{2}{*}{ Kesimpulan } & \multirow{2}{*}{ Keterangan } \\
\hline & Statistic & $\mathrm{df}$ & Sig. & & \\
\hline MEAs & 0.266 & 37 & 0.000 & Ho ditolak & Tidak Normal \\
\hline Konvensional & 0.169 & 38 & 0.008 & Ho ditolak & Tidak Normal \\
\hline
\end{tabular}

Kriteria keputusannya jika nilai signifikansi atau probabilitas $>0.05$ maka distribusi adalah normal (Riduwan et al, 2011). Berdasarkan hasil perhitungan Tabel 2 dengan menggunakan uji Kolmogorov-Smirnova pada nilai probabilitas pada kolom signifikansi data pre-test untuk kelas eksperimen adalah 0.000 dan kelas kontrol adalah 0.008 Hal ini terlihat bahwa baik kelas eksperimen mapun kelas konvensional memiliki nilai Sig. $<\propto(\propto$ $=0,05)$ sehingga Ho ditolak, maka dapat disimpulkan bahwa kelas konvensional berdistribusi tidak normal. Oleh karena itu tidak perlu dilakukan uji homogenitas melainkan langsung menggunakan Uji Non-Parametric Mann-Whitney U.

Tabel 3. Uji Perbedaan Rataan Skor Pre-Test Kemampuan Berfikir Kritis

\begin{tabular}{lcccc}
\hline Skor & Mann-Whitney U & $\mathrm{Z}$ & Asymp. Sig. (2-tailed) & Keterangan \\
\hline Pre-Test & 565.000 & -1.466 & 0.143 & Ho Diterima \\
\hline
\end{tabular}

Hasil Uji Mann-Whitney U diperoleh nilai Sig. (2-tailed) $(\propto=0,05)<0.143$ (Tabel 3), hal ini menunjukkan bahwa Ho diterima, artinya Hal ini menunjukkan bahwa Ho diterima, artinya tidak terdapat perbedaan rata-rata skor pre-test kemampuan berfikir kritis secara signifikan antara mahasiswa yang belajar dengan MEAs dengan mahasiswa yang 
belajar dengan pembelajaran konvensional. Dengan kata lain kedua kelas memiliki kemampuan awal berfikir kritis matematis mahasiswa yang sama sehingga untuk melihat pencapaian kemampuan berfikir kritis matematis mahasiswa dapat dilihat melalui skor post-test (Tabel 4).

Tabel 4. Uji Normalitas Skor Post-Test Kemampuan Berfikir kritis

\begin{tabular}{|c|c|c|c|c|c|}
\hline \multirow{2}{*}{ Kelas } & \multicolumn{3}{|c|}{ Kolmogorov-Smirnov $^{\mathrm{a}}$} & \multirow{2}{*}{ Kesimpulan } & \multirow{2}{*}{ Keterangan } \\
\hline & Statistic & $\mathrm{df}$ & Sig. & & \\
\hline MEAs & 0.110 & 37 & 0.200 & Ho diterima & Normal \\
\hline Konvensional & 0.149 & 38 & 0.033 & Ho ditolak & Tidak Normal \\
\hline
\end{tabular}

Kriteria keputusannya jika nilai signifikansi atau probabilitas $>0.05$ maka distribusi adalah normal (Riduwan et al, 2011). Berdasarkan hasil perhitungan Tabel 4 dengan menggunakan uji Kolmogorov- Smirnova pada nilai probabilitas pada kolom signifikansi data post-test untuk kelas MEAs adalah 0.200 dan kelas kontrol adalah 0.033. Kelas konvensional terlihat bahwa memiliki nilai Sig. $<\propto(\propto=0.05)$ sehingga Ho ditolak, maka dapat disimpulkan bahwa kelas konvensional berdistribusi tidak normal. Oleh karena itu tidak perlu dilakukan uji homogenitas melainkan langsung menggunakan uji NonParametric Mann-Whitney U. Setelah diketahui bahwa data skor post-test tidak memenuhi syarat kenormalan, maka dilanjutkan dengan menggunakan Mean-Whitney U.

Tabel 5. Uji Perbedaan Rataan Skor Post-Test Kemampuan Berfikir Kritis

\begin{tabular}{ccccc}
\hline Skor & Mann-Whitney U & Z & Asymp. Sig. (2-tailed) & Keterangan \\
\hline Post-Test & 447.000 & -2.716 & 0.007 & Ho Ditolak \\
\hline
\end{tabular}

Hasil uji Mann-Whitney U diperoleh nilai Sig. (2-tailed) yaitu $\propto(\propto=0.05)>0.007$ (Tabel 5). Hal ini menunjukkan bahwa Ho ditolak, artinya terdapat perbedaan rata-rata skor pre-test kemampuan berfikir kritis secara signifikan antara mahasiswa yang belajar dengan MEAs dengan mahasiswa yang belajar dengan pembelajaran konvensional.

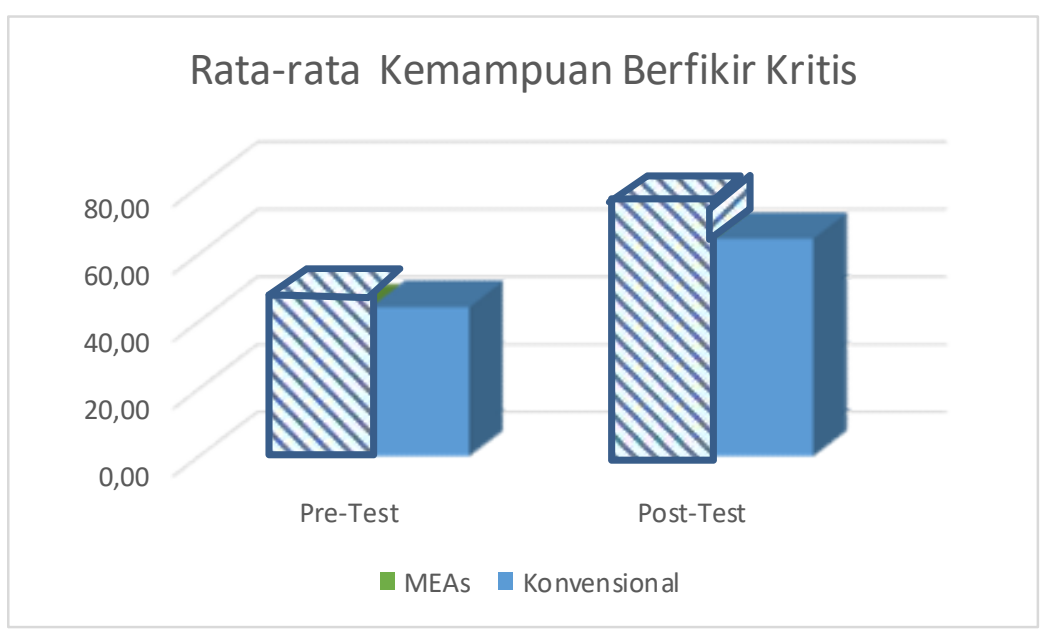

Gambar 1. Nilai Rata-rata Mahasiswa Kelas Eksperimen dan Kontrol. 
Hasilnya menunjukkan bahwa mahasiswa dalam kelas eksperimen memiliki kemampuan berfikir kritis yang lebih baik daripada kelas kontrol setelah perlakuan $(\bar{x}=71.73,64.87)$ (Gambar 1).

Setiap mahasiswa memiliki kemampuan yang berbeda-beda baik dalam kelas eksperimen maupun kelas kontrol. Pembelajaran dalam kelas eksperimen (MEAs) memberikan kesempatan bagi mereka dengan kemampuan belajar metematika yang rendah untuk belajar dari anggota kelompok yang lebih mampu. Selain itu, mahasiswa memiliki lebih banyak kesempatan untuk mendiskusikan kembali pembahasan soal disediakan dalam lembar kerja yang dimiliki masingmasing mahasiswa. Mereka tidak hanya belajar apa yang dilakukan oleh tim lain, mereka juga harus mengungkapkan pikiran mereka (kemampuan berfikir kritis).

Proses pembelajaran MEAs dapat menumbuhkan aspek sosial yaitu memberikan respon yang baik dalam kemampuan berfikir kritis dalam pemecahan masalah yang diberikan. Artinya, Pendekatan Model-Eliciting Activities (MEAs) dalam pembelajaran matematika merupakan suatu alternatif pendekatan yang dapat meningkatkan kemampuan berpikir kritis matematik peserta didik agar terus terlatih dengan baik (Istianah, 2013; Wessels, 2014; Mulia., \& Fauzan, 2018; Chotimah., Ramdhani., Bernard., \& Akbar, 2019).

Dalam penelitian ini, kegiatan proses pembelajaran matematika ekonomi dengan pendekatan MEAs yang dapat meningkatkan kompetensi kemampuan berfikir kritis dan berlatih secara bersama-sama baik dalam satu kelompok maupun antar kelompok. Hal ini dapat menciptakan lingkungan belajar yang memungkinkan lebih baik dan efisien dalam meningkatkan hasil belajar yang lebih baik dengan menyelesaikan tugas-tugas tertentu yang konteks dan situasi yang baru. Efektivitas model pembelajaran menggunakan MEAs adalah serupa dengan penelitian sebelumnya yang menemukan bahwa pembelajaran MEAs dapat memberikan dampak yang baik pada pembelajaran (Irvine et al., 2016; Festiana., Firman., Setiawan., \& Muslim, 2019).

Hasil survei yang dilakukan dalam penelitian terungkap bahwa mahasiswa yang menggunakan pembelajaran matematika ekonomi menjukan pencapaian kemampuan berfikir kritis mahasiswa yang belajar dengan MEAs (eksperimen) lebih baik daripada kelas kontrol (konvensional) (Tabel 5). Hal ini karena Pertama pembelajaran MEAs memberikan pembelajaran yang memberikan kesempatan kepada mahasiswa untuk dapat lebih aktif dengan mengekspresikan ide (kemampuan berfikir kritis) dalam memecahkan masalah secara bersama-sama, namun pelaksanaan pembelajaran MEAs memiliki kekurangan waktu dalam melaksanakan latihan dan diskusi, Kedua pembelajaran MEAs dapat memberikan kemudahan kepada mahasiswa untuk dapat memahami, dan menjelaskan konsep matematika ekonomi dalam pemodelan matematika melalui diskusi kelompok sehingga dapat menumbuhkan kemampuan berfikir kritis, denagn cara meninjau ulang kembali solusi atau pemecahan masalah yang telah diberikan, Ketiga pembelajaran MEAs; mahasiswa yang memiliki kemampuan matematika yang rendah memiliki cara mereka sendiri dalam merespon permasalahan yang diberikan melalui diskusi kelompok. 
Mereka menyadari bahwa pembelajaran MEAs benar-benar membantu untuk meningkatkan kemampuan berfikir kritis. Hal ini karena pembelajaran MEAs memberikan banyak kesempatan mengungkapkan ide dalam pemecahan masalah. Pembelajaran menggunakan MEAs peserta didik dapat belajar secara aktif (Eraslan, 2012; Istianah, 2013). Mahasiswa menjadi lebih aktif ketika mereka ditugaskan untuk melakukan beberapa kegiatan di lingkungan pembelajaran MEAs. Mahasiswa secara berkelompok dengan model pembelajaran MEAs dapat lebih mungkin untuk belajar dan berlatih dari dosen, dan teman sejawat baik dalam kelompok maupun antar kelomok. Temuan itu ditemukan mirip dengan penelitian Hidayat (2014) yang menjelaskan bahwa secara analisis pengalaman pengguna pembelajaran MEAs berpotensi melibatkan peserta didik dalam tugas matematika sehingga dapat mengembangkan kemampuan peserta didik. Hasil penelitian penerapan pembelajaran MEAs memberikan lingkungan proses pembelajaran matematika ekonomi kepada mahasiswa untuk meningkatkan kemampuan kompetitif mahasiswa yaitu kemampuan berfikir kritis untuk memecahkan masalah dalam menghadapi kebutuhan industry yang dinamis (revolusi industri 4.0).

\section{KESIMPULAN}

Hasil penelitian adalah pencapaian kemampuan berfikir kritis mahasiswa kelas eksperimen (MEAs) lebih baik daripada kelas kontrol (konvensional) pada pembelajaran matematika ekonomi. Strategi pembelajaran MEAs dapat digunakan sebagai salah satu alternatif pembelajaran untuk melatih kerja sama dalam proses belajar mengajar.

\section{REKOMENDASI}

Rekomendasi melalui penerapan pembelajaran MEAs, dosen/guru atau pendidik harus memperhatikan dalam penyediaan perangkat pembelajaran, alokasi waktu, pembagian kelompok kelas disesuaikan dengan kemampuan awal matematika peserta didik. Pendidik harus dapat membangun komunikasi dengan semua kelompok untuk dapat mendeteksi ruang perbaikan, membimbing dan mengarahkan aktivitas mahasiswa sehingga pencapain berfikir kritis lebih maksimal.

\section{UCAPAN TERIMAKASIH}

Peneliti mengucapkan terima kasih kepada DRPM dan Universitas Bina Bangsa karena telah memberikan dukungan finansial. Peneliti mengucapkan terima kasih kepada pihak yang telah membantu dan berkontribusi dalam diskusi atau pengolah data yang terkait langsung dalam kegiatan penelitian. 


\section{REFERENSI}

Afrilianto, M. (2015). Pengaruh Pendekatan Model-Eliciting Activities Terhadap Kemampuan Komunikasi Matematik Siswa SMP. P2M STKIP Siliwangi, 2(1), 4045.

Chamberlin, S. A., \& Moon, S. M. (2008). How does the problem based learning approach compare to the model-eliciting activity approach in mathematics. International Journal for Mathematics Teaching and Learning, 9(3), 78-105.

Chotimah, S., Ramdhani, F. A., Bernard, M., \& Akbar, P. (2019). Pengaruh Pendekatan Model-Eliciting Activities Terhadap Kemampuan Berpikir Kritis Matematik Siswa SMP Negeri di Kota Cimahi. Journal on Education, 1(2), 68-77.

Eraslan, A. (2012). Prospective Elementary Mathematics Teachers' Thought Processes on a Model Eliciting Activity. Educational Sciences: Theory and Practice, 12(4), 29642968.

Facione, P. A. (2011). Critical thinking: What it is and why it counts. Insight assessment, 2007(1), 1-23.

Farida, N. (2015). Pengembangan Pemahaman Konsep dan Kemampuan Pemecahan Masalah dalam Membentuk Model Matematika Melalui Strategi Pembelajaran Inquiry Bagi Mahasiswa Prodi Pendidikan Matematika Universitas Kanjuruhan Malang. Jurnal Inspirasi Pendidikan, 5(2), 663-669.

Festiana, I., Firman, H., Setiawan, A., \& Muslim, M. (2019, February). Design and development of model-eliciting activity in energy and electrical power topics. In Journal of Physics: Conference Series (Vol. 1157, No. 3, p. 032047). IOP Publishing.

Hamidah. 2014. Penerapan Pembelajaran MEAs untuk Mengembangkan Retensi Kemampuan Representasi Matematik Siswa SMA. Prosiding Seminar Nasional Pendidikan Matematika STKIP Siliwangi. Volume 2, p.74.

Hidayat, W. (2014). The Implementation of MEAs Instruction to Students' Mathematics Problem Solving and Connecting Ability. In Proceeding of International Conference on Research, Implementation and Education of Mathematics and Sciences.

Irvine, J., Telford, W., Anusic, V., \& Alves, P. (2016). A Straightforward Model Eliciting Activity and the Power of "What If?" in Supporting Students' Higher-Order Thinking. Betty Jones \& Sisters Publishing, 3, 7-22.

Istianah, E. (2013). Meningkatkan Kemampuan Berpikir Kritis dan Kreatif Matematik dengan Pendekatan Model Eliciting Activities (MEAS) pada Siswa SMA. Infinity Journal, 2(1), 43-54.

Krathwohl, D. R., \& Anderson, L. W. (2009). A taxonomy for learning, teaching, and assessing: A revision of Bloom's taxonomy of educational objectives. Longman.

McMillan, J., \& Schumacher, S. (1997). Research in Education: A conceptual Introduction $\left(4 \mathrm{th}^{\mathrm{ed}}\right)$.

Mulia, U. O., \& Fauzan, A. (2018, July). The Effectiveness of Learning Device with Model Eliciting Activities (MEAS) to Improve Critical Thinking Ability. In 2nd International Conference on Mathematics and Mathematics Education 2018 (ICM2E 2018). Atlantis Press. 
Muzaki, A. (2014). Meningkatkan Kemampuan Berfikir Kritis dan Kreatif Matematik Siswa MTs Negeri 1 Jonggat Dengan Pembelajaran Tasc (Thinking, Actively dan Social Context) Pada Materi Segitiga. Media Pendidikan Matematika, 2(1), 8-13.

Noordyana, M. A. (2016). Meningkatkan Kemampuan Berpikir Kritis Matematis Siswa melalui Pendekatan Metacognitive Instruction. Mosharafa: Jurnal Pendidikan Matematika, 5(2), 120-127.

Rahmawati, N. D. (2016). Model Pembelajaran Inovatif Matematika Pada Mahasiswa. JURNAL e-DuMath, 2(2).

Riduwan, Rusyana, Enas. (2011). Statistika Penelitian untuk manajemen dan Bisnis: Alfabeta. Bandung.

Smith, Mark K. 2010.Teori Pembelajaran dan Pengajaran. Yogyakarta: Mirza Media Pustaka.

Syah, M. (2006). Psikologi Belajar, Jakarta: PT. Raja Grafindo Persada.

Wessels, H. M. (2014). Levels of mathematical creativity in model-eliciting activities. Journal of Mathematical Modelling and Application, 1(9), 22-40

Yuliardi, R., \& Habibi, M. I. (2016). Implementasi Pembelajaran Berbasis Komputer Menggunakan Software Geogebra Terhadap Peningkatan Kemampuan Komunikasi Matematis Siswa SMK di Kota Kuningan. JUMLAHKU: Jurnal Matematika Ilmiah STKIP Muhammadiyah Kuningan, 2(2), 201-211.

Zetriuslita, Z., Ariawan, R., \& Nufus, H. (2016). Analisis kemampuan berpikir kritis matematis mahasiswa dalam menyelesaikan soal uraian kalkulus integral berdasarkan level kemampuan mahasiswa. Infinity Journal, 5(1), 56-66. 